\title{
Nota de Agradecimento
}

Na ocasião em que me afasto do cargo de Editor-Chefe de Pesquisa Operacional, gostaria de deixar registrados meus penhorados agradecimentos ao Prof. Paulo Oswaldo Boaventura Netto, da COPPE/UFRJ, por sua inestimável colaboração no período de transição para a gestão do novo Editor, Dr. Horácio Hideki Yanasse, do INPE. O Prof. Boaventura foi o responsável pela parte gráfica do Vol. 19 No. 2 e do presente Vol. 20 No. 1, que puderam contar com sua valiosa experiência nesta área, sendo assim publicados sem maiores atrasos e dentro de elevado padrão de qualidade gráfica.

Roberto Diéguez Galvão 